\title{
Phytic Acid Extracted from Rice Bran as a Growth Promoter for Euglena gracilis
}

https://doi.org/10.1515/chem-2019-0006

received July 3, 2018; accepted October 26, 2018.

\begin{abstract}
A significant promotion of growth and accumulation of metabolites of freshwater microalga Euglena gracilis was obtained by adding phytic acid to the culture. Phytic acid concentration of $0.05 \%(\mathrm{v} / \mathrm{v})$ showed a maximum biomass increase of 1.6 -fold compared to the control group. Synchronous variation in the content and proportion of photosynthetic pigments was also observed. The total chlorophyll content increased with phytic acid concentration, suggesting the enhanced capacity of absorbing light. Cell length, an important biomarker for E. gracilis, was prolonged to a certain extent under light condition, indicating the state of the cells was more active. Since phytic acid is derived from agro waste of rice bran, it is promising as a low-cost but high-efficient growth promoter of E. gracilis.
\end{abstract}

Keywords: phytic acid; Euglena gracilis; photosynthetic pigments; cell morphology.

\section{Introduction}

Euglena gracilis is one of the primary producers in fresh water ecosystems which has both animal and plant features [1]. When there is sufficient sunlight, it can produce many beneficial metabolites with high commercial value by photosynthesis. Nowadays with the deeper understanding of functions of $E$. gracilis, it has been widely applied in food, cosmetic and biofuel industries [2,3]. Faced with the increasing market demand from consumers, understanding how to shorten the

\footnotetext{
*Corresponding author: Minato Wakisaka, Graduate School of Life Science and Systems Engineering, Kyushu Institute of Technology, Kitakyushu, Japan, E-mail: wakisaka@life.kyutech.ac.jp Jiangyu Zhu: Graduate School of Life Science and Systems Engineering, Kyushu Institute of Technology, Kitakyushu, Japan Dang Diem Hong: Department of Algal Biotechnology, Institute of Biotechnology, Vietnam Academy of Science and Technology, Hanoi, Vietnam
}

culture cycle and enhance the productivity of valuable metabolites has become a top priority. Several of the most common methods are to screen for excellent algal strains [4], edit key genes associated with metabolism [5], or add growth-promoting additives [6]. Each method has its own merits and drawbacks. Strain screening is usually timeconsuming and low efficiency with a long cycle. Geneediting makes up for these shortcomings but this method is expensive and the process is complex. Application of gene-edited microorganisms for food and supplements is also a controversial issue [7]. Another common method is supplementing with various types of functional additives, such as exogenous nutrients [8] and phytohormone [9], but they are still costly in application for large-scale culture.

Alternative ideas for supplements with low cost and high efficiency were recently proposed. It was reported that $1 \mathrm{~g} / \mathrm{L}$ alginate oligosaccharides extracted from macroalgae could increase the production of Arthrospira platensis by 3.68-fold [10], and $5 \mathrm{~g} / \mathrm{L}$ steel-making slag (by-product of steel processing) could increase the yield of $A$. platensis by $12 \%$ [11]. Enhancing microalgae yield by un-utilized or waste materials was considered a novel and promising strategy. Phytic acid (inositol hexakisphosphate, IP6), a principle storage form of phosphorus in plants tissues, is widespread in nature especially in legume seed, cereal bran and germ. Phytic acid is also an excellent chelating agent and antioxidant [12]. Thus, phytic acid easily exists in the form of metal-salts and is able to scavenge free radicals, preventing DNA damage and cell aging [13]. The safety of phytic acid has been confirmed in many fields, and its toxicity is even lower than sodium chloride [14]. Moreover, it is also the major source of phosphate loading in aquatic ecosystems [15]. A large number of seeds and grains are used for animal fodder but non-ruminants, like swine, fowl, and horses, cannot fully digest phytic acid due to their lack of sufficient corresponding enzymes, and then undigested phytic acid and derivatives in the manure will be excreted to aquatic ecosystems in different ways [16]. Therefore, intelligent use of phytic acid could contribute to relieving environmental load to aquatic ecosystem. 
Phytic acid with the above-mentioned characteristics are considered as potential candidates as a microalgae growth promotor. Nevertheless, there are no reports that phytic acid and its metal-salts have been used to improve the growth and metabolism of microalgae. As a simple, cheap but efficient approach of enhancing the yield of $E$. gracilis, the effect of phytic acid from rice bran on $E$. gracilis was investigated. Cell growth, photosynthetic pigment content and morphology of $E$. gracilis were analyzed since these were assumed to be clear indicators to determine the effect of the phytic acid. This research is initial work that will contribute to sufficiently using the agricultural waste and increasing the yield of $E$. gracilis on a large scale.

\section{Materials and Methods}

\subsection{Organism and cultivation conditions}

Euglena gracilis Klebs (NIES-48) obtained from the National Institute for Environmental Studies (NIES) of Japan, was incubated in axenic Cramer-Myers (CM) medium with the following composition $(\mathrm{mg} / \mathrm{L})$ : $\left(\mathrm{NH}_{4}\right)_{2} \mathrm{HPO}_{4}$, $1000 ; \mathrm{KH}_{2} \mathrm{PO}_{4}, 1000 ; \mathrm{MgSO}_{4} \cdot 7 \mathrm{H}_{2} \mathrm{O}, 200 ; \mathrm{CaCl}_{2} \cdot 2 \mathrm{H}_{2} \mathrm{O}$, 20; $\mathrm{FeSO}_{4} \cdot 7 \mathrm{H}_{2} \mathrm{O}, 3 ; \mathrm{MnCl}_{2} \cdot 4 \mathrm{H}_{2} \mathrm{O}, 1.8 ; \mathrm{CoSO}_{4} \cdot 7 \mathrm{H}_{2} \mathrm{O}, 1.5$; $\mathrm{ZnSO}_{4} \cdot 7 \mathrm{H}_{2} \mathrm{O}, 0.4 ; \mathrm{Na}_{2} \mathrm{MoO}_{4} \cdot 2 \mathrm{H}_{2} \mathrm{O}, 0.2 ; \mathrm{CuSO}_{4} \cdot 5 \mathrm{H}_{2} \mathrm{O}, 0.02$; Vitamin $\mathrm{B}_{12}, 0.0005$; Thiamine $\mathrm{HCl}, 0.1$. Pure phytic acid extracted from rice bran was provided by Tsuno Rice Fine Chemicals Co., Ltd. For cultivation, $10 \mathrm{~mL}$ of algal cells during logarithmic growth stage were inoculated into $250 \mathrm{~mL}$ Erlenmeyer flasks and stock solution of phytic acid was then added, with each flask finally containing $100 \mathrm{~mL}$ medium. The appropriate concentration range of phytic acid was determined according to the $\mathrm{pH}$ and the final concentrations were $0.001 \%, 0.01 \%, 0.05 \%$ and $0.2 \%(\mathrm{v} / \mathrm{v})$. Euglena gracilis cells were cultured at $25^{\circ} \mathrm{C}$ and continuously illuminated under the light condition of $5000 \mathrm{~lx}$ by cool-white fluorescent lamps (12:12h lightdark cycle). During the culture, flasks were shaken evenly by hand twice a day to avoid cells from adhering to the bottom. In addition, the $\mathrm{pH}$ of the medium was measured weekly for four weeks using a pH meter (LAQUA-2103AL, Horiba, Japan).

\subsection{Growth evaluation}

Cell growth was primarily assessed by cell density and dry weight. Cells were counted periodically through a hemocytometer chamber (Thoma, Hirschmann, Germany) under the microscope during the growth process. At the end of the cultivation, cells were harvested by filtration and then washed three times to remove the reagents. After microalgal biomass deposited on the filter paper was dried in the oven at $120^{\circ} \mathrm{C}$ for 2 hours and the dry weight of the biomass was calculated by comparing the weight of the filter paper before and after drying.

\subsection{Pigment determination}

The chlorophyll a, chlorophyll b and carotenoid content was estimated using Lichtenthaler's method [17]. Algal cells in the stationary phase were filtered with glass fiber filters (Advantec Grade-GC50, pore size $<0.45 \mu \mathrm{m}$ ) and the fresh algal biomass was crushed with glass sand and extracted using $80 \%$ acetone. When the photosynthetic pigments were totally dissolved in acetone, the samples were filtered again to remove glass sand and broken cells. The extract was then transferred into $10 \mathrm{~mL}$ volumetric flask. Specific content of chlorophyll a, chlorophyll $b$ and carotenoid was determined using a spectrophotometer (UV-vis 1200, Shimadzu, Japan) with the absorption at $470 \mathrm{~nm}, 645 \mathrm{~nm}$ and $663 \mathrm{~nm}$, respectively. The ratio of chlorophyll a to b was calculated as well.

\subsection{Cell morphology}

Cell morphology was observed and recorded by microscope (Model BA210a, Motic, Japan) and corresponding software (Motic Image Plus 2.2S). The length of more than 200 cells were measured using image-processing software (Image $J$ ) at the sixth hour of light and dark cycle respectively as the intensity of photosynthesis was supposed to be high in light condition and low in dark condition.

\subsection{Phosphate comparison experiment}

Comparison of phosphorus source between phytic acid and phytate was also supplemented. Optimal dosage of phytic acid treatment and the same amount of phosphate treatment were compared in this experiment, since the effect of phosphate on $E$. gracilis has been investigated thoroughly [18]. For phosphate treatment group, potassium dihydrogen phosphate was added to adjust phosphorus content equivalent to the phytic acid treatment group. Concentration of phytic acid and phosphate was $1.085 \mathrm{mM}$ $(0.05 \%$; v/v) and $6.51 \mathrm{mM}$ respectively, and the phosphorus 
content was both $6.51 \mathrm{mM}$. The $\mathrm{pH}$ of phosphate treatment group was adjusted to the same level as phytic acid treatment group by adding dilute hydrochloric acid, with other culture conditions unchanged and only the source of phosphorus different. Finally, the dry weight and total chlorophyll content were determined.

\subsection{Statistical Analysis}

All cultures were performed in triplicate. Data was processed using statistical software SPSS 17.0 and eventually expressed as mean \pm standard deviation. The data was tested for normality and homogeneity of variances. Post-hoc analysis of variance (ANOVA) and Dunnett's test were used to test for differences in the growth and metabolism parameters between the target algae cultures treated with different concentrations of phytic acid and the control with a significance level of $p=$ 0.05 .

Ethical approval: The conducted research is not related to either human or animal use.

\section{Results}

\subsection{Growth promotion of $E$. gracilis by phytic acid}

Considerable growth promotion of $E$. gracilis by phytic acid was observed from the beginning of cultivation. Growth curve (A) and dry weight (B) of E. gracilis with various concentrations of phytic acid are shown in Figure 1. As seen from the growth curve, growth of E. gracilis was significantly promoted by phytic acid and the effect was concentration-dependent. The promotion effect was increased with phytic acid concentration and showed a maximum increase, $1.6-$ fold, at $0.05 \%(\mathrm{v} / \mathrm{v})$. When the concentration increased to $0.2 \%(\mathrm{v} / \mathrm{v})$ the promotion effect slowed but the cell density is still significantly higher than that of the control group $(p<0.05)$.

The dry weight of biomass (B) was also assessed to confirm the significance and consistency with the growth curve. Dry weight of biomass increased with phytic acid concentration, from $0.34 \pm 0.03 \mathrm{~g} / \mathrm{L}$ of control group to 0.52 $\pm 0.04 \mathrm{~g} / \mathrm{L}$ of $0.05 \%(\mathrm{v} / \mathrm{v})$ group. However similar with the growth curve of cell density, the dry weight also decreased to $0.45 \pm 0.04 \mathrm{~g} / \mathrm{L}$ in $0.2 \%$ (v/v) phytic acid treatment group.

Change in initial $\mathrm{pH}$ by phytic acid treatment is shown in Table 1. In the control group, the initial $\mathrm{pH}$ was 6.9 which
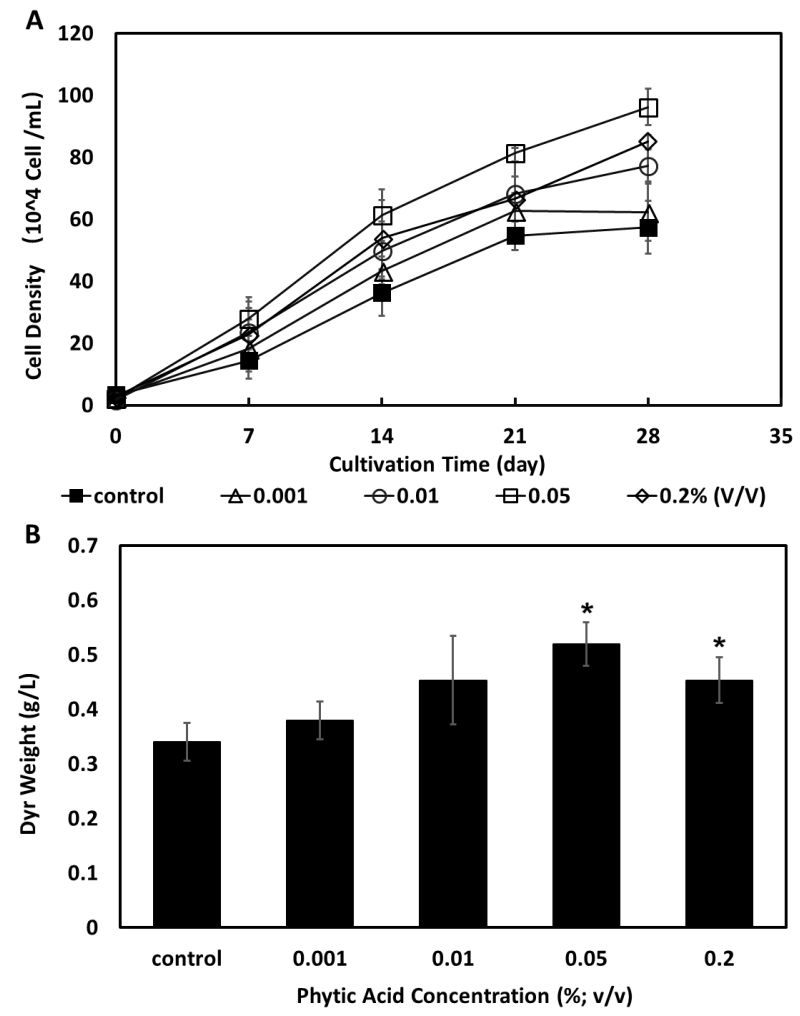

Figure 1: Effect of phytic acid on growth the profile of $E$. gracilis. (A) Growth curve, (B) Dry weight of Biomass. Asterisks indicate the significant difference $(p<0.05)$ between the experimental and control groups.

was optimal for cell growth [19]. CM medium contains a large amount of diammonium phosphate and potassium hypophosphite and has a wider buffer range for the $\mathrm{pH}$. Therefore, the change in $\mathrm{pH}$ was not significant at lower concentration of phytic acid treatment. When phytic acid concentration was $0.05 \%(\mathrm{v} / \mathrm{v})$ the $\mathrm{pH}$ decreased to 6.3 , however, when the concentration was increased to $0.2 \%$ $(\mathrm{v} / \mathrm{v})$ the $\mathrm{pH}$ drastically decreased to 2.3. In addition, during the culture $E$. gracilis, the $\mathrm{pH}$ of the medium decreased slightly as well.

\subsection{Effect of phytic acid on photosynthetic pigment content of $E$. gracilis}

As shown in Figure 2, phytic acid affected intracellular pigments (chlorophyll a, chlorophyll $\mathrm{b}$ and carotenoid) content, with an increase of chlorophyll a content on the dry basis notably observed, increasing from $2.35 \pm$ $0.41 \%$ to $4.16 \pm 0.23 \%$, with a maximum at $0.05 \%(\mathrm{v} / \mathrm{v})$, then decreasing to $3.72 \pm 0.38 \%$ at $0.2 \%$ (v/v) phytic acid treatment. However, the change of chlorophyll $b$ content 
Table 1: Change in pH at different concentrations of phytic acid.

\begin{tabular}{|c|c|c|c|c|c|}
\hline \multirow{2}{*}{$\begin{array}{l}\text { Phytic acid concentration } \\
(\% ; v / v)\end{array}$} & \multicolumn{5}{|c|}{$\mathrm{pH}$ of the medium during the culture } \\
\hline & $\mathbf{0 d}$ & $7 \mathrm{~d}$ & $14 \mathrm{~d}$ & $21 \mathrm{~d}$ & $28 \mathrm{~d}$ \\
\hline 0 & 6.9 & 6.9 & 6.8 & 6.6 & 6.5 \\
\hline 0.001 & 6.8 & 6.8 & 6.6 & 6.5 & 6.5 \\
\hline 0.01 & 6.6 & 6.6 & 6.3 & 6.2 & 6.2 \\
\hline 0.05 & 6.3 & 6.2 & 6.1 & 6.0 & 5.9 \\
\hline 0.2 & 2.3 & 2.5 & 2.4 & 2.4 & 2.3 \\
\hline
\end{tabular}

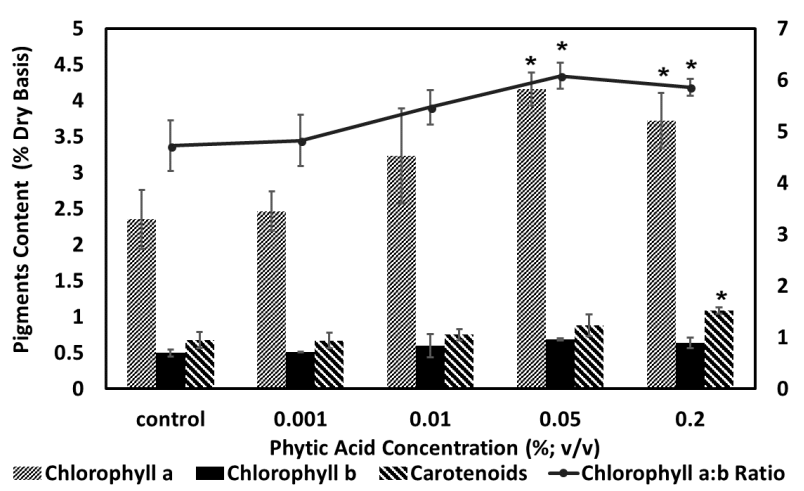

Figure 2: Effect of phytic acid on pigment content of E. gracilis. Asterisks indicate the significant difference $(p<0.05)$ between the experimental and control groups.

was not significant $(p>0.05)$ even though its trend was similar to chlorophyll a. As for carotenoid, its content remained almost the same at lower concentrations of phytic acid, but significantly increased at $0.2 \%(\mathrm{v} / \mathrm{v})$. In addition, an increase of chlorophyll a over chlorophyll b ratio was observed by phytic acid, especially at concentrations of $0.05(\mathrm{v} / \mathrm{v})$ and $0.2 \%(\mathrm{v} / \mathrm{v})$.

\subsection{Cell length of E. gracilis increased by phytic acid}

Euglena gracilis cell shape and median cell length were notably influenced by phytic acid compared to the control group. Cell length distribution at different concentrations of phytic acid treatment are illustrated in Figure 3.

At the sixth hour of light cycle, $81.82 \%$ of the cells in the control group were less than $29 \mu \mathrm{m}$ in length and the median cell length was $22.11 \mu \mathrm{m}$. With the addition of phytic acid, cells longer than $29 \mu \mathrm{m}$ increased, especially at $0.05 \%(\mathrm{v} / \mathrm{v})$, its population increased from $18.18 \%$ to the highest amount of $41.82 \%$, and median cell length also increased to $28.48 \mu \mathrm{m}$ correspondingly.

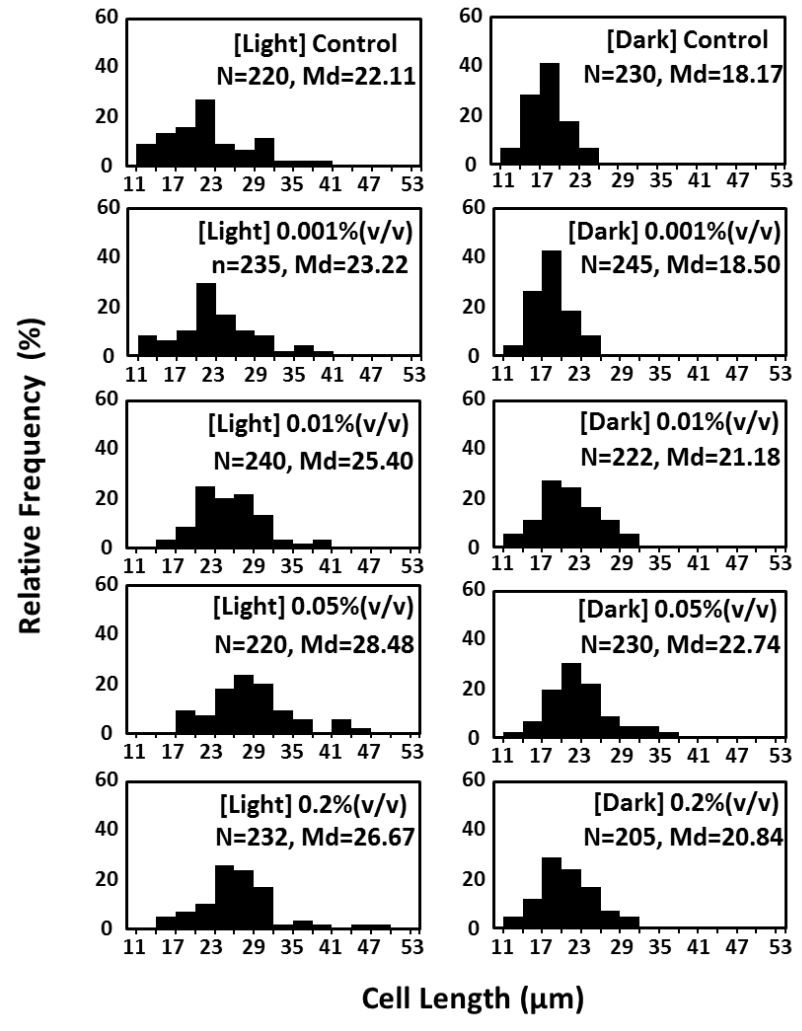

Figure 3: Effect of phytic acid on cell length distribution. [Dark] and [Light] represents the dark and light period respectively. $\mathrm{N}$ represents the number of samples (cell volume). Md represents the median cell length.

The effect of phytic acid on cell length in the dark cycle was similar but less than that observed during the light cycle. Longer cells also appeared with the addition of phytic acid. In the control group, cell varied in length from 11 to $26 \mu \mathrm{m}$, while in phytic acid treatment groups it ranged from 11 to $38 \mu \mathrm{m}$. Median cell length was prolonged as well, increasing from $18.17 \mu \mathrm{m}$ in the control group to $22.74 \mu \mathrm{m}$ of $0.05 \%(\mathrm{v} / \mathrm{v})$ for the phytic acid treatment group, while ratio of elongation was less than that of the light cycle. 


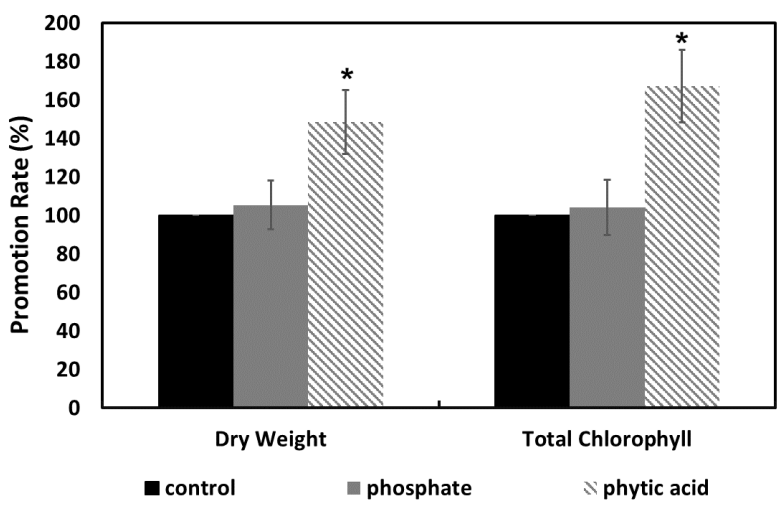

Figure 4: Comparison of phytic acid and phosphate for their effect on the dry weight and total chlorophyll content of $E$. gracilis. Concentration of phytic acid and phosphate was $1.085 \mathrm{mM}$ and 6.51 $\mathrm{mM}$, respectively (phosphorus content was $6.51 \mathrm{mM}$ ). Asterisks indicate the significant difference $(p<0.05)$ between experimental and control groups.

\subsection{Comparison of phytic acid with phosphate}

In Figure 4, the effect of phytic acid and phosphate on the dry weight and total chlorophyll content of E. gracilis was determined as the promotion rate, considering the control group as $100 \%$. A significant promotion effect by phytic acid $(1.085 \mathrm{mM})$ to dry weight and total chlorophyll content of $48.65 \%$ and $67.25 \%$ respectively was obtained $\left(p_{1} \& p_{2}<0.05\right)$, while there was no significant difference to the control group for the addition of phosphate (6.51 mM) even though the amount of phosphorus added were the same (6.51 mM).

\section{Discussion}

Significant growth stimulation of $E$. gracilis by phytic acid from rice bran was obtained in this research. The various indicators of growth we obtained are within a reasonable range and consistent with previously reported values [20]. The safety of phytic acid has been verified. In the acute toxicity test of mice the median lethal dose (LD50) of phytic acid was found to be up to $4220 \mathrm{mg} / \mathrm{kg}$ [14]. Hence the method to promote the growth of $E$. gracilis by simply adding phytic acid is very safe.

Phytic acid is a good source of phosphorus as one molecule of phytic acid contains six phosphorus atoms. However, enzymatic hydrolysis is necessary for the use of phosphorus in phytic acid. Similar growth promotion effect of phytic acid were observed for some plant, animal and microorganism which contains enzyme so called phytase.
For instance, after the addition of phytic acid, the yeast yield increased from $45.1 \%$ to $71.7 \%$ with the assistance of phytase [21], and erythritol production in yeast was also enhanced greatly [22]. In another experiment, phytate was reported to serve as the sole phosphate source for growth of Tetrahymena, a heterotrophic protist in the marine system, and eventually A170 kDa phytase located in the cell membrane facing the exterior of the cell was proved to involve the absorption and utilization of phytate [23].

As shown in Figure 4, the same amount of phosphate was not significant, suggesting that the promotion of phytic acid was not simply attributed to the supply of a phosphorus source. It might also be related to the secondary metabolite of phytic acid. Phytase is a type of phosphatase enzyme that can eventually catalyze the hydrolysis of phytic acid into phosphate and inositol. The former is the main component of cell membranes and nucleic acid which can provide materials for cell division, while the latter has been corroborated as a growthpromotion and bioactive factor. Cho et al. [24] reported that supplementation in a Dunaliella salina culture medium with $0.05 \%$ myo-inositol led to approximately 1.4 fold increase in cell density, 1.48-fold increase in biomass yield and 1.34-fold increase in neutral lipids. If the catabolic pathway of phytic acid or related phytase was determined as well with E. gracilis, it could be of help to understand how phytic acid or its secondary metabolites (lower inositol and polyphosphates) stimulated growth of E. gracilis.

As for the increase of total chlorophyll content in phytic acid treatment group, chlorophyll a played a major role. On the basis of insignificant change of chlorophyll b, the content of chlorophyll a increased, which led to the ratio increase between chlorophyll a and chlorophyll b, indicating the capacity of capturing and utilizing the light enhanced. Chlorophyll content usually depends on the nutrient content such like nitrogen, essential metal ions like iron, zinc and magnesium [25]. Here we inferred that the increase of chlorophyll content was mainly due to the increase of intracellular essential metal ions, as phytic acid has strong binding affinity to these divalent metal ions. In the high concentration of phytic acid treatment group, growth and chlorophyll content decreased, but carotenoid content increased. This could be the stress response due to $\mathrm{pH}$ decrease. Optimal pH for E. gracilis was reported neutral or weakly acidic $[19,26]$, but $\mathrm{pH}$ declined to 2.3 at the concentration of $0.2 \%(\mathrm{v} / \mathrm{v})$ phytic acid as shown in Table 1 . Chlorophyll content usually decreased under severe circumstances, as its structure was unstable, while carotenoid content would increase to cope with stress [27]. 
We found that cell length during the light cycle was longer than that obtained during the dark cycle. Euglena gracilis cells could exhibit many shapes with different length in relation to the variation of culture conditions [28]. As reported that E. gracilis cells changed shapes periodically with the light-dark cycle and photosynthesis [29]. In the dark period when the photosynthetic capacity was low, cells were usually in spherical shape; while they stepped into light period, the cell length of the population would increase and reach the maximum at the sixth hour of the light period, which was in agreement with our observation. Cell length elongation was proportional to phytic acid concentration, and it was more obvious during light period than dark period. This may reflect the enhancement of photosynthesis capacity, since chlorophyll content increased as well. On the other hand, a larger population of longer and narrower cells also indicated more vitality of $E$. gracilis.

\section{Conclusion}

In summary, a significant promotion effect on growth of $E$. gracilis was achieved by simply adding phytic acid. Phytic acid concentration of $0.05 \%(\mathrm{v} / \mathrm{v})$ showed a maximum biomass increase of 1.6-fold compared to the control group $(p<0.05)$, which was better than the effect of phosphate which contained equal amount of phosphorus (6.51 mM). In the future, with the large-scale application of phytic acid in the cultivation of $E$. gracilis, it will contribute to improving the economy of microalgae culture, and full utilization of agro wastes such as rice bran at the same time.

Acknowledgments: We would like to thank Tsuno Rice Fine Chemicals Co., Ltd. for providing the phytic acid extracted from rice bran.

Conflict of interest: Authors declare no conflict of interest.

\section{References}

[1] Cramer M., Myers J., Growth and photosynthetic characteristics of Euglena gracilis. Arch. Microbiol., 1952, 17, 384-402.

[2] Borowitzka M.A., High-value products from microalgae-their development and commercialisation. J. Appl. Phycol., 2013, 25, 743-756.

[3] Harun R., Singh M., Forde G.M., Danquah M.K., Bioprocess engineering of microalgae to produce a variety of consumer products. Renewable Sustainable Energy Rev., 2010, 14, 1037-1047.

[4] Ruiz L.B., Rocchetta I., Ferreira V.S., Conforti V., Isolation, culture and characterization of a new strain of Euglena gracilis. Phycol. Res., 2004, 52, 168-173.

[5] Rosenberg J.N., Oyler G.A., Wilkinson L., Betenbaugh M.J., A green light for engineered algae: redirecting metabolism to fuel a biotechnology revolution. Curr. Opin. Biotechnol., 2008, 19, 430-436.

[6] Ogbonna J.C., Tomiyamal S., Tanaka H., Heterotrophic cultivation of Euglena gracilis Z for efficient production of $\alpha$-tocopherol. J. Appl. Phycol., 1998, 10, 67-74.

[7] Wolfenbarger L.L., Phifer P.R., The Ecological Risks and Benefits of Genetically Engineered Plants. Science, 2000, 290, 2088-2093.

[8] Ogbonna E., Ichige H., Tanaka J., Interactions between photoautotrophic and heterotrophic metabolism in photoheterotrophic cultures of Euglena gracilis. Appl. Microbiol. Biotechnol., 2002, 58, 532-538.

[9] Raman V., Ravi S., Effect of salicylic acid and methyl jasmonate on antioxidant systems of Haematococcus pluvialis. Acta Physiol. Plant., 2010, 33, 1043-1049.

[10] Nogami R., Nishida H., Hong D.D., Wakisaka M., Growth promotion effect of alginate oligosaccharides on Spirulina analyzed by repeated batch culture. J. Jpn. Inst. Energy., 2017, 96, 352-356.

[11] Nogami R., Nishida H., Hong D.D., Wakisaka M., Growth promotion of Spirulina by steelmaking slag: application of solubility diagram to understand its mechanism. AMB Express, 2016, 6, 96

[12] Graf E., Antioxidant functions of phytic acid. Free Radical Biol. Med., 1990, 8, 61-69.

[13] Mallick N., Mohn F.H., Reactive oxygen species: response of algal cells. J. Plant Physiol., 2000, 157, 183-193.

[14] Wu M., Yuan J., Toxicological evaluation and food safety of phytic acid. Food Sci., 1997, 18, 46-49, (in Chinese).

[15] Minear R.A., Segars J.E., Elwood J.W., Mulholland P.J., Separation of inositol phosphates by high-performance ionexchange chromatography. Analyst., 1988, 113, 645.

[16] Dersjant-Li Y., Awati A., Schulze H., Partridge G., Phytase in non-ruminant animal nutrition: a critical review on phytase activities in the gastrointestinal tract and influencing factors. J. Sci. Food Agric., 2014, 95, 878-896.

[17] Lichtenthaler H.K., Wellburn A.R., Determinations of total carotenoids and chlorophylls $\mathrm{a}$ and $\mathrm{b}$ of leaf extracts in different solvents. Biochem. Soc. Trans., 1983, 11, 591-592.

[18] Kempner E.S., The biology of Euglena, 1st ed., Academic press, New York, 1982.

[19] Danilov R.A., Ekelund N.G.A., Effects of $\mathrm{pH}$ on the growth rate, motility and photosynthesis in Euglena gracilis. Folia Microbiol., 2001, 46, 549-554.

[20] Zhu J.Y., Wakisaka M., Growth promotion of Euglena gracilis by ferulic acid from rice bran. AMB Express, 2018, 8, 16.

[21] Graf E., Applications of phytic acid. J. Am. Oil Chem. Soc., 1983, $60,1861-1867$.

[22] Lee J.K., Ha S.J., Kim S.Y., Oh D.K., Increased erythritol production in Torula sp. with inositol and phytic acid. Biotechnol. Lett., 2001, 23, 497-500. 
[23] Ziemkiewicz H.T., Johnson M.D., Smith-Somerville H.E., Phytate as the Sole Phosphate Source for Growth of Tetrahymena. J. Eukaryotic Microbiol., 2002, 49, 428-431.

[24] Cho K., Kim K.N., Lim N.L., Kim M.S., Ha J.C., Shin H.H., et al., Enhanced biomass and lipid production by supplement of myo-inositol with oceanic microalga Dunaliella salina. Biomass Bioenergy., 2015, 72, 1-7.

[25] Murata N., Tashiro H., Takamiya A., Effects of divalent metal ions on chlorophyll a fluorescence in isolated spinach chloroplasts. Biochim. Biophys. Acta., 1970, 197, 250-256.

[26] Lane A.E., Burris J.E., Effects of Environmental pH on the Internal pH of Chlorella pyrenoidosa, Scenedesmus quadricauda, and Euglena mutabilis. Plant Physiol., 1981, 68, 439-442.

[27] Borowitzka M.A., Borowitzka L.J., Kessly D., Effects of salinity increase on carotenoid accumulation in the green alga Dunaliella salina. J. Appl. Phycol., 1990, 2, 111-119.

[28] Li M., Muñoz H.E., Goda K., Carlo D.D., Shape-based separation of microalga Euglena gracilis using inertial microfluidics. Sci. Rep., 2017, 7, 10802-10811.

[29] Lonergan T.A., Regulation of cell shape in Euglena gracilis: I. involvement of the biological clock, respiration, photosynthesis, and cytoskeleton. Plant Physiol., 1983, 71, 719-730. 